\title{
Summary and Update on Behavioural Interventions for Improving Adherence with Positive Airway Pressure Treatment in Adults
}

Angela L. D’Rozario $\mathrm{PhD}^{1,2,3}$, Yael Galgut PGDip (ProfPsych)', Megan Crawford $\mathrm{PhD}^{4}$, Delwyn J. Bartlett $\mathrm{PhD}^{2,3}$

1) School of Psychology, Faculty of Science, Brain and Mind Centre and Charles Perkins Centre, The University of Sydney, NSW, Australia 2) Sleep and Circadian Research Group, Woolcock Institute of Medical Research, The University of Sydney, Sydney, NSW, Australia 3) Sydney Medical School, The University of Sydney 4) The University of Strathclyde, Glasgow, UK

\section{Email Addresses and Postal Addresses}

angela.drozario@sydney.edu.au, elle.galgut@sydney.edu.au, megan.crawford@strath.ac.uk, delwyn.bartlett@sydney.edu.au

A.L.D, Y.G, D.J.B: Woolcock Institute of Medical Research, PO Box M77, Missenden Road, Camperdown, Sydney, 2050, New South Wales, Australia. M.C.: Graham Hills Building, University of Strathclyde, 50 George Street, Glasgow, G1 1QE, UK

\section{Corresponding Author:}

Dr Angela D'Rozario, School of Psychology Faculty of Science, University of Sydney

Sleep and Circadian Research Group, Woolcock Institute of Medical Research, PO Box M77, Missenden Road, NSW 2050, Australia angela.drozario@sydney.edu.au

\section{Disclosure Statement}

The authors have nothing to disclose. 


\section{Key Words}

Adherence; compliance; obstructive sleep apnea; behavioral interventions; psycho-education; psychosocial factors; cognitive behavioural therapy; sleep-disordered breathing

\section{Key Points}

- Despite initial uptake and adherence to PAP treatment, ongoing use is generally not maintained by 3-6 months.

- Continued support (phone calls, booster sessions) are recommended for improved adherence outcomes. Positive messages around PAP that are repeated frequently and ease of access to health professionals are crucial.

- Approaches to identify the characteristics of those most at-risk of non-adherence should be explored at the time of OSA diagnosis and again at 1-2 weeks after initiating treatment.

- Individualised and tailored interventions can optimise adherence. The patient's perspective - feeling heard and concerns met - is an important consideration.

\section{Synopsis}

Continuous positive airway pressure (PAP) is still the most efficacious treatment for obstructive sleep apnea (OSA) when used effectively. Since the availability of PAP 39 years ago there have been considerable technological advances such as quieter, lighter and smaller machines with better humidification. However, adherence to treatment is still a major problem. This paper will review studies published on behavioural interventions aimed at improving the uptake and maintenance of PAP treatment (January 2016-February 2020). It will discuss underlying factors in the poor uptake and discontinuation of treatment and the role of qualitative research to better understand the patients' perspective. 


\section{BACKGROUND}

\section{Prevalence and Burden of OSA}

OSA is a prevalent sleep disorder characterised by chronic fragmentation, intermittent hypoxia resulting in considerable comorbidity and mortality ${ }^{1}$. Recent research estimated 1 billion men and women aged 30-69 years had OSA with and without symptoms and in some countries there is a prevalence of up to $50 \%{ }^{2}$. OSA is also prevalent in older adults ${ }^{3}$ with a burgeoning cost to health care systems ${ }^{4}$. Untreated OSA in older adults was associated with increased utilization of primary care visits and hospital admissions, occurring 5-10 years before the diagnosis of OSA ${ }^{4}$. With a rapidly ageing population, ${ }^{5}$ it is crucial to screen earlier for OSA and optimise current treatment approaches ${ }^{6}$.

\section{Effects of PAP Treatment}

PAP therapy stabilises nocturnal oxygen saturation levels, normalises sleep architecture, improves daily functioning and reduces physical, psychological and neurocognitive comorbidity when used effectively ${ }^{7,8}$. PAP treatment potentially reduces the risk for adverse cardiovascular events ${ }^{9}$. However, in the large SAVE trial (Sleep Apnea Cardiovascular Endpoints), ${ }^{10}$ the low PAP usage of 3.3 hours/night was a factor in not reducing CVD mortality over 3.7 years ${ }^{11}$. Moreover, the CVD patients were possibly more concerned about their cardiac diagnosis compared with their OSA as many were asymptomatic ${ }^{12}$. PAP treatment must be perceived by the individual as having physical and psychological benefits. Moreover, poor adherence in large clinical trials impedes the evaluation of PAP on comorbidities ${ }^{13}$.

Effective PAP use can reduce accidents in the workplace and on the road and improve neurocognitive function and mood ${ }^{14-17}$. However, not all cognitive deficits are reversed ${ }^{18}$. 
Despite these positive effects, one night of not using PAP can result in the return of apneas and hypopneas and associated impairments/risks ${ }^{13}$.

There is wide inter-individual variability in the subjective and objective response to hours of PAP use. Improved subjective and objective sleepiness ${ }^{19}$ and quality of life ratings occurred with $>5$ hours of PAP per night, ${ }^{14}$ whilst 7 hours produced the most effective improvement in symptoms ${ }^{16}$. Four hours or more of PAP use can improve neurocognitive function ${ }^{20}$ whilst 6 hours can normalise memory ${ }^{16}$. However improving neurocognitive function with PAP may be dependent on the presence of daytime sleepiness which in turn influences adherence ${ }^{21}$. Even one hour of PAP is better than no PAP ${ }^{22}$, whilst using PAP across the night, every night potentially beneficial health outcomes.

\section{Challenges with PAP Adherence}

Despite considerable technological advances to equipment including humidifiers and the availability of quieter and more portable machines, PAP adherence continues to be low. In the first week to six months the dropout rate ranges from $5-50 \%{ }^{23}$ with the first three days being critical $^{24}$. Adherence thresholds to PAP usage ${ }^{25-27}$ of 4.7 hours per night or 4 hours on $70 \%$ of the nights used is problematic for sustaining positive health outcomes when most individuals sleep for approximately 7 hours each night.

Factors that may determine the uptake and continuation of PAP therapy include race/ethnicity, socio-economic and income status, education level, age, obesity, gender, smoking, as well as nasal congestion and nasal function i.e., deviated septum; however, outcomes in terms of continuation of treatment are variable despite the presence of these factors within the individual ${ }^{28-30}$. Treatment intervention in asymptomatic patients is particularly challenging. Patients who are minimally symptomatic have a reduced likelihood of successful PAP treatment compared with those with persistent symptoms of being sleepy ${ }^{31,32}$. 


\section{Challenges around Side Effects of using PAP}

Mask-related difficulties with leakages, skin soreness and overall mask discomfort often drive discontinuation. The type of mask selected at titration impacts on initial acceptance. Switching to a different mask was associated with a 7.2 odds ratio of giving up PAP treatment in the first year ${ }^{33}$ even with a $61 \%$ resolution of physical difficulties occurred. Women were 1.2 times more likely to change masks, which may relate to most masks being originally designed for men. Other commonly reported side-effects include nasal stuffiness, a dry mouth/throat and frequent awakenings, claustrophobia, as well as the general inconvenience of using the device and maintaining/cleaning equipment ${ }^{23,34-38}$.

Technological improvements such as trialling different mask interfaces ${ }^{39-41}$ or, enhancing device capability such as heated humidification ${ }^{42,43}$ and flexible pressure delivery ${ }^{44,45}$ are continually being tested. In a meta-analysis, auto-titrating PAP resulted in an extra 13 minutes/night around six weeks than those using fixed-pressure PAP and heated humidification results in an additional 0.37 hours of PAP use ${ }^{46}$. Craniofacial phenotyping ${ }^{47}$ and engineering approaches for customising mask interfaces to fit the individual ${ }^{48}$ appear to be important future strategies for enhancing PAP adherence.

\section{PATIENTS' PERSPECTIVE: QUALITATIVE RESEARCH IN PAP USAGE}

In their guidance document on complex interventions, the Medical Research Council alluded to the importance of considering qualitative methodologies for the development and evaluation of complex treatments ${ }^{49}$. PAP is a complex intervention and several qualitative methodologies have been adopted to explore the barriers and facilitators of PAP use. PAP naïve patients do not all start from the same baseline and the need for more consideration of their perspective 
and willingness to undertake this difficult treatment is backed up by numerous cross-sectional and some longitudinal qualitative investigations. Some individuals struggle using their PAP machine, which they believe identifies them as ill, odd or not able to take care of themselves 50-53 or they experience side effects, which have repeatedly been voiced as a barrier to continued PAP use ${ }^{50,51,54-57}$. Social support can help many patients increase their PAP use and includes spousal support ${ }^{50,51,54-56,58,59}$. However, not all spousal input is the same and partners who are too invasive can negatively impact on PAP use ${ }^{58}$. Regular PAP users find themselves having to utilise internal means, such as willpower, positive attitudes and self-efficacy ${ }^{54,55,60}$, and engage in a cost-benefit evaluation ${ }^{55,59}$. If advantages (especially the elimination of negative consequences of OSA and witnessing improvements in functioning) outweigh the disadvantages, this can lead to engagement in the treatment. From these qualitative studies, adherence to PAP is not a one-stop decision where patients either adhere or not, but a dynamic process.

In a qualitative study with 61 patients prescribed PAP, Zarhin and Oksenberg explored the dynamic nature and found ambivalence towards PAP in both regular users and those who rejected PAP outright/after one night of use ${ }^{53}$. There was evidence in both groups that the behaviour (use PAP vs. reject PAP) is not synonymous with specific beliefs about PAP. Those who accepted it sometimes doubted its use, and those who rejected it sometimes re-evaluated their decision. Even 18 months after rejecting the PAP, individuals in the non-adherent group had doubts around rejecting the treatment and queried potential benefits. In the adherence group, patients reported not being satisfied with this non-aesthetic treatment. They were ashamed of using it in front of partners or grandchildren and frustrated that it was not a cure for OSA. 
Many adherers reported intermittent interruptions in use either while traveling or during the night, i.e., taking the mask off in the middle of the night after waking up. Often patients report taking off the mask after a few hours of use in order to be "free" 53 of the machine and finally get a "proper sleep" ${ }^{59}$. This mask off behaviour might be driven by the cut-off information of 4 hours, in the literature as a level of optimal use, despite evidence for continued improvement beyond this cut-off ${ }^{16}$. This behaviour is witnessed clinically, yet it is rarely investigated quantitatively. In a recent commentary ${ }^{61}$ it was suggested how the decision to wear PAP to bed occurs during waking hours, whereas the middle of the night is a time where decisionmaking is impaired. The decision to keep the mask on after waking up in the middle of the night may be impaired by sleep inertia, heightened emotions during our circadian night, or the sleep/bed context i.e., a sleeping partner who cannot offer support. In summary, PAP use is a dynamic process, and future research (quantitative and qualitative) which requires more explicit investigation.

\section{BEHAVIOURAL TREATMENT INTERVENTIONS TO INCREASE ADHERENCE}

This section provides a background of behavioural treatments used to increase adherence and includes psychosocial interventions; cognitive behavioural therapy (CBT); motivational enhancement; standard care and educational programs; and combined treatments.

A review of educational, supportive and behavioural approaches showed that most studies used more than one intervention to address PAP adherence ${ }^{62}$. In treatment naïve patients, behavioural therapy showed the largest effect of 1.44 hours of additional PAP usage and more patients using their machine for $>4$ hours/night, compared with supportive and educational interventions ${ }^{62}$. 


\section{Psychosocial Interventions}

The work by Bandura ${ }^{63,64}$ on social cognitive theory (SCT) created another perspective on the impact of psychosocial factors which could be applied to PAP adherence. This perspective is based on self-efficacy and how an individual can stick with and maintain a treatment when faced with considerable difficulties. Risk perception of the disorder, outcome expectancies of the treatment process and the coping mechanisms are key components of this model ${ }^{65-67}$. Components of self-efficacy can be explored using the Ways of Coping questionnaire ${ }^{67}$ and the self-efficacy measure in sleep apnea (SEMSA) ${ }^{68}$. Self-efficacy has been assessed at numerous time points of PAP treatment ${ }^{65,66,69,70}$ however it is unclear whether it changes with PAP usage or is a baseline predictor of adherence ${ }^{71-73}$. However an increase of one point higher on the self-efficacy scale did predict one more hour of PAP usage in the intervention group at 6 months ${ }^{71,72}$, and lower self-efficacy scores indicate the need for increased support ${ }^{69,74}$.

\section{Cognitive Behavioral Therapy (CBT)}

CBT for PAP adherence was initially a combination of components that educated patients on their disease severity and efficacy of treatment, helped set goals and discussed realistic treatment expectations ${ }^{75}$. No group adherence differences were found at one and four weeks however by 12 weeks the intervention group used their PAP for 3.2 hours longer compared with the control group ${ }^{75}$. Two brief behavioural therapies (education and motivational enhancement) decreased PAP drop-outs compared with standard care at three months ${ }^{76}$. A group-based CBT approach increased PAP use by 2.9 hours/night and uptake at one month, compared with treatment as usual (TAU) ${ }^{71}$.

\section{Motivational Interviewing/Enhancement}

The Health Belief Model explores the cues, e.g. health, partner or health professional cues, that enable individuals to initiate and continue to use PAP despite encountering difficulties ${ }^{77}$. 
Combining motivational interviewing around healthy lifestyles (diet/exercise) to increase positive expectations associated with change i.e., of using PAP, resulted in an additional 1.5 hours/night compared with the control group at 12 months ${ }^{78}$.

In a 3-arm randomised control trial (RCT) there was no difference in the rate of decline in PAP adherence across 12 months between educational, motivational enhancement and standard care groups but usage decreased in all groups ${ }^{79}$. Retrospectively stratifying patients based on adherence in the first week, motivational enhancement appeared more effective in moderate users, high users responded more to the educational intervention, and low PAP users did not show benefits. Patient profiling at this early stage to tailor the best intervention for the individual may enhance adherence ${ }^{79,80}$.

A brief motivational enhancement education program plus standard care increased PAP usage by 2 hours/night with a 4 -fold increase in adherence compared with standard care at three months ${ }^{81}$. Self-efficacy was also increased in this intervention. In a health action process selfefficacy, outcome expectations and risk perception all improved PAP adherence at 3 months 82. However, unequal time exposure for both control arms of these studies highlights the ongoing difficulties around what constitutes 'standard care'.

A proof of concept trial aimed to increase PAP in previously non-adherent patients ${ }^{83}$. Following an educational session, if there was less than a $25 \%$ improvement in adherence, patients were randomised to either motivational enhancement treatment or self-management treatment. Both additional interventions were effective (based on $>4$ hours/night) highlighting effective interventions for baseline non-adherent PAP. 


\section{Standard Care and Educational Programs}

Standard patient education is difficult to assess as the specific content, evaluation and effectiveness of the programs used is often lacking ${ }^{84}$. Educational strategies include slide presentations, videos, general discussions/demonstrations. Timing of PAP education pre or post titration, and personal contact often determines PAP uptake and adherence. A 4-tiered intervention strategy with reinforced sessions (additional per need) compared with standard care, increased PAP usage to $>5$ hours/night from 3-12 months. High rate PAP users could account for this finding ${ }^{85}$ however the frequency of the booster sessions is a more likely long term factor.

An early seminal multimodal intervention compared with standard care increased adherence by 1.6 hours/night at six months ${ }^{86}$. However, this program was labour intensive and expensive. A more recent but less intensive multimodal intervention of individual education and a slide presentation in a group setting enhanced PAP usage by $>1$ hour/night ${ }^{87}$.

\section{Telehealth and Support-Based Approaches}

Telephone counselling and peer support may provide feasible, cost-effective programs to improve PAP adherence ${ }^{88}$. In a parallel RCT of 379 OSA patients, five sessions of telephonebased coaching (15-20 mins) increased both the proportion of adherent users and PAP usage after four months of treatment ${ }^{89}$.

In a smaller parallel RCT of 40 OSA patients, daily phone reinforcement messages from their sleep doctor, in the first week and at one month increased adherence. This outcome was not sustained at one year ${ }^{90}$. After using PAP for one month, 146 OSA patients were randomly assigned to a 1-hour group-based education intervention or to no education resulting in no differences in adherence ${ }^{91}$. Early support in the initiation process, and ongoing support appears necessary to optimise ongoing adherence to PAP ${ }^{92}$. 
In a study of 3100 OSA patients, an intensive support program (physicians and nurses) significantly increased PAP adherence relative to usual care (6.9 vs. 5.2 hours/night) after two years ${ }^{93}$. The program reduced sleepiness, improved mood, quality of life, and lowered CVD morbidity and mortality. Partners and family accompanied the patient during the follow-up care. In another similar study, (predominantly nurse-led) positive outcomes were observed on PAP adherence at one year highlighting personal contact roles ${ }^{94}$.

A pilot study of "peer buddies" (experienced PAP users) was introduced to promote adherence in veteran OSA patients ${ }^{95}$. The peer buddies shared their experiences and coping strategies which improved usage at 3 months. Patient satisfaction of the peer buddy system was high and correlated to adherence.

\section{The Role of Partners in PAP Adherence}

The presence of a partner increases PAP usage compared to no partner ${ }^{96}{ }^{97}$ potentially improving the bedpartner's sleep ${ }^{98}$. In a review approaching spousal support from a dyad framework perspective, social support (ways of coping and response to stressors) and control were significant adherence factors. ${ }^{99}$. A small study introducing a 1-day educational program including partners did not significantly increase adherence ${ }^{100}$. In a CBT study, social support was a significant factor in adherence but not partner participation ${ }^{71}$. Being unmarried and having more variation in bedtimes ( $>75$ minutes) was associated with more non-adherence at one month ${ }^{101}$. Overall the role of the immediate social environment and important close relationships appear to positively impact adherence ${ }^{69}$. 


\section{UPDATED RESEARCH: BEHAVIOURAL TREATMENT INTERVENTIONS TO INCREASE ADHERENCE}

This section extends an earlier review of behavioural interventions to improve PAP adherence 102. It focusses on new approaches that have emerged in the last 4 years and explores their impact and practicality.

\section{Methods}

An electronic search was conducted using Scopus, Medline, PsychInfo and Embase databases. The search terms included ('Sleep Apnea' OR 'Obstructive Sleep Apnea') AND ('CPAP Adherence' OR 'Continuous Positive Airway Pressure' OR 'Positive Airway Pressure') AND (behavio?r* intervention* OR 'Behavi?r* Therap*' OR 'behavio? $\mathrm{r}^{*}$ treatment'). The search was limited to include full-text and English language publications between the 1 January 2016 and 8 February 2020 and included only articles which outlined a behavioural intervention to increase PAP adherence. All articles were reviewed for relevance by title, abstract and if necessary full-text. We excluded articles if they (1) did not focus on behavioural interventions, (2) did not outline a randomised control trial and (3) did not include a measure of PAP adherence as an outcome and (4) did not include adult subjects.

\section{Results}

The combined search produced 128 articles of which 44 were duplicates. After filtering the selection based on the exclusion criteria, 12 articles were selected for inclusion ${ }^{103-114}$. We serendipitously found two additional papers ${ }^{115,116}$ from searching the references as we were reviewing potential articles for inclusion in review. Fourteen articles therefore met inclusion criteria and are outlined in Table 1. One ${ }^{110}$ of the 14 articles did employ an RCT design and was therefore selected for inclusion, however, the authors did not statistically compare the 
effects of the intervention and control groups on adherence outcomes due to not reaching the required sample size, but instead reported effect sizes.

\section{Psychosocial Interventions}

A different modelling approach (CPAP-SAVER) was introduced to increase PAP adherence in 66 patients randomised to the intervention or usual care ${ }^{112}$. The Theory of Planned Behaviour seeks to understand how personal, social, internal and environmental factors influence what individuals intend to do and what they do. Attitude, social pressure, anxiety, self-efficacy, or perceived personal control were key components. Within the first week of using PAP the risks and benefits were explored, with a video, education handouts an adherence report card and nurse led telephone calls. At one-month adherence (4 hours on $70 \%$ of nights) was not different between the groups on weekly hours 154.1 hours (intervention) vs. 161 hours (control). However, positive attitude and beliefs around PAP use was significantly higher in the intervention group compared with the control group. These positive responses around PAP may positively influence adherence.

Twenty couples were randomised to a couple orientated education, patient only education or usual care ${ }^{110}$. Though this study was designed as an RCT the target sample size was not reached and comparisons between the interventions were not made. However, within the couple oriented intervention PAP use improved by 1.6 hours between 1 week and 1 month but returned to baseline levels at 3 months, again highlighting how few studies maintain initial adherence.

118 PAP patients were randomised to either a targeted intervention exploring social cognitive perceptions (TI) around OSA and PAP usage or usual care (UC) ${ }^{111}$. TIs are theory based and customised towards the patients' specific characteristics. There were $4 \mathrm{x}$ timed interventions from pre-diagnostic PSG, to one week of using PAP. A patient response of $<3$ on the SEMSA resulted in exploring that specific identified domain in the next session ${ }^{68}$. At one week the TI 
group were using PAP for 35 minutes longer than the UC group which was not maintained at three months. PAP usage was high at one week (6.1 hours) in both groups which dropped to 4.8 hours at three months, highlighting support roles.

\section{Motivational Enhancement}

Motivational Enhancement previously used in PAP studies aims at empathetically and collaboratively directing ambivalence associated with change to enable a positive outcome such as PAP adherence. An open-label parallel-arm of 83 OSA and established or at-risk CVD patients were randomised to PAP education or PAP education plus motivational enhancement 103. Regular appointments were offered for both groups whilst the motivational enhancement group had 2 psychologist led appointments with 6 phone calls over 32 weeks. At 6 months there was an 80-minute increase in adherence in the PAP plus motivational enhancement group, whilst at 12 months adherence was 97 minutes longer however there was considerable dropout at this time-point. The motivational enhancement intervention was effective independently of baseline sleepiness, self-efficacy, depression and insomnia symptoms and place of recruitment.

\section{CBT}

Insomnia is prevalent comorbid disorder in patients with OSA ${ }^{117}$. A CBT intervention for insomnia (CBT-I) involved 145 patients who had both diagnosed OSA and insomnia ${ }^{118}$. In this RCT patients underwent 4 sessions of CBT-I or treatment as usual (TAU). All patients received standard care for PAP. Follow-up was at 1 week, 3 and 6 months and data were downloaded and reviewed. The CBT-I group increased their adherence by 61 minutes along with insomnia symptoms reducing to subclinical. Higher functional beliefs and sleep efficiency of $84 \%$ at 6 months were significant. Unequal face to face time for the TAU group was a limitation with no significant differences in mood, sleepiness or fatigue. 


\section{Educational Programs}

212 at-risk patients for low adherence were randomised to attend either an educational video or usual care before a split night study for an OSA diagnosis and PAP titration ${ }^{106}$. The 4minute video (SAVE-CPAP), contained information about untreated OSA, benefits of using PAP and what is a sleep study. At 30 days there was no significant group differences in hours of PAP (3.3 vs. 3.5 hours/night UC). CPAP adherence was greater if patients had attended college for $\geq 4$ years and if they responded positively to a statement about using PAP every night. Targeting "at-risk" PAP non-users early is important but recruitment in this group is also difficult.

\section{Telehealth Approaches}

Seven studies have assessed the utility of telemonitoring to improve PAP adherence $104,105,107,108,114-116$ with varying effects.

A multicentre RCT of 306 patients with moderate to severe OSA and high cardiovascular risk evaluated the effects of a multimodal telemonitoring program to reduce blood pressure (BP) after 6 months of auto-titrating PAP treatment ${ }^{116}$. The telemonitoring system included homebased measures of BP and physical activity / sleep duration (actimetry) for 3 days before PAP initiation and after 6 months of treatment; quality of life and symptom questionnaires at baseline and at 6 months; with PAP adherence and side effects data. The telemonitoring did not reduce systolic BP compared to usual care at 6 months, however PAP usage was significantly higher (5.3 vs. 4.8 hours/ night). Other RCTs have shown that PAP treatment alone does not reduce cardiovascular morbidity or mortality, ${ }^{9,10}$ which may in part be explained by poor adherence. Empowering patients to be engaged in and to monitor their own PAP management using telemonitoring appears to improve adherence, quality of life and daytime sleepiness ${ }^{116}$ despite the lack of effect on cardiovascular risk. 
In post-ischemic stroke patients with co-morbid moderate to severe OSA, a simpler telemonitoring intervention (Infomart Web, Fisher and Paykel Healthcare) increased at-home auto-titrating PAP usage compared to usual care at 6 months (4.4 vs. 2.1 hours/night) ${ }^{108}$. The intervention consisted of daily reports of PAP adherence, pressures, mask leak and residual respiratory events which were reviewed weekly by sleep lab staff. Patients were contacted via phone if the weekly mean usage time had dropped below 4 hours/night with 5 mins calls ${ }^{108}$. Telemonitoring reduced daytime sleepiness (ESS) and systolic BP levels in post-stroke patients further supporting its use to address poor compliance in this vulnerable clinical population.

Telemonitoring (T4P Vision Web Portal) using similar daily reports delayed the time to the first technical intervention after PAP initiation, though the proportion of interventions were not different than usual care ${ }^{104}$. In this study of 47 patients, the early monitoring of technical problems via the web portal appeared to be an important factor in improving adherence at 3 months compared to usual care (5.7 vs. 4.2 hours/night).

In contrast, another telemonitoring system (MyOSA-OXigen Salud web database) that also captured similar daily information (adherence, pressures, leak and residual respiratory events) did not improve auto-titrating PAP usage (4.9 vs. 5.1 hours/night), quality of life or daytime sleepiness (ESS) compared to usual care after 3 months ${ }^{114}$. The "alert" criteria for the sleep lab staff to intervene in this study did differ from Hoet et al. ${ }^{104}$ : (Turino, leak $>30 \mathrm{~L} / \mathrm{min}$ for $>30 \%$ of the night, or usage of $<4 \mathrm{~h} /$ night on two consecutive nights vs. Hoet, leak $>50 \mathrm{~L} / \mathrm{min}$, residual AHI $>10 / \mathrm{h}$, or PAP use $<3$ h on three consecutive nights) which may account for the inconsistent results, whilst patients in the latter study used auto-titrating PAP. Though telemonitoring did not improve adherence compared to usual care in this trial it was significantly less expensive and more cost effective in terms of reducing the number of clinic visits. Patients did however report lower satisfaction with this intervention ${ }^{114}$. 
The use of automated feedback messaging delivered alone, or in combination with telemedicine-delivered education improved PAP usage compared to usual care or telemedicine education alone at 3 months ${ }^{105}$. In this 4 -arm RCT of 556 patients, nightly average adherence was 4.4 vs. 4.8 vs. 3.8 vs. 4.0 hours/night for telemonitoring alone (automated feedback messages based on device usage, U-Sleep ${ }^{\mathrm{TM}}$ ), combined telemonitoring with telemedicine education ( 2 x 15 min web-based OSA education sessions), usual care, and telemedicine education alone, respectively. After the 3 month intervention had ceased, adherence gradually declined to similar levels as those observed in patients who had never received feedback when followed-up at 1 year suggesting that sustained telemonitoring feedback was necessary to maintain higher adherence. Technology-based solutions that provide automated feedback directly from PAP devices may offer a cost-effective strategy to motivate patients to improve their adherence, however their utility needs to be assessed over the longer term.

An earlier and smaller RCT ${ }^{107}$ that tested the same telemonitoring system of text message feedback (U-Sleep ${ }^{\mathrm{TM}}$, ResMed) over the same treatment period of 3 months, reported no difference in adherence compared with usual care. However, the telehealth approach did positively impact on health professionals time thus reducing pressure on health care services 107. When adherence was assessed after a short follow up period of 1 month using telemonitoring (Restraxx ${ }^{\mathrm{TM}}$, ResMed) there was no significant difference in auto-titrating PAP usage, when compared to usual care or weekly phone calls (5.0 vs. 5.1 vs. 3.9 hours/night), however this 3-arm RCT did have a small sample size of 51 patients which limits the interpretation of these results ${ }^{115}$. 


\section{SUMMARY}

Innovative interventions to improve PAP adherence over the last four years have resulted in effective outcomes in the initial treatment (1 week to 1 month) or no significant effect over this period ${ }^{106,112}$. However, those studies that have assessed adherence over the longer term (3 months to 1 year) have produced minimal or negative adherence outcomes ${ }^{110,111}$. The exceptions were in two co-morbid populations with interventions of motivational enhancement with follow-up at 12 months and CBT-I at 6 months ${ }^{113}$. Four ${ }^{104,105,108,116}$ of the seven telemonitoring RCTs increased adherence at 3 months ${ }^{104,105}$ and 6 months ${ }^{108,116}$ while 3 studies showed no difference compared to usual care at 1 month ${ }^{115}$ or 3 months ${ }^{107,114}$.

\section{CLINICAL CARE POINTS}

1. Exploring baseline patient characteristics including self-efficacy i.e., SEMSA assessment, can be useful to identify those patients who are at-risk of not taking up PAP or dropping out.

2. Using targeted interventions based on patient's cognitive perceptions to OSA and PAP treatment increases adherence.

3. Being diagnosed with OSA is a time of considerable change with associated stress. Motivational enhancement with a goal-orientated and very personal approach may be more useful for populations more at-risk of non-adherence. Asking questions around "what is the patient prepared to do and how important is it for that person to learn to adapt to this chronic disorder?"

4. Both CBT-I and motivational enhancement were effective in comorbid populations at 6 and 12 months follow-up. Booster sessions (phone calls, telemedicine, face to face 
sessions) and ongoing contact with a known health professional appear to be crucial components of long-term adherence.

5. The effectiveness of telehealth approaches was variable. Beneficial effects of telemonitoring may be dependent of several factors e.g. baseline patient characteristics, method and regularity of the feedback delivered, alert criteria thresholds for triggering an 'intervention'. Reduced time commitment and costs for patients i.e., for clinic visits, and less burden on health services costs and professional input are factors requiring exploration in future telehealth interventions.

\section{Points Around Enhancing PAP Usage}

- Health - stopping breathing has medical consequences.

- Relief of symptoms - waking with a headache, dry mouth or bruised ribs!

- Partner disturbance - snoring and apneas; sleeping separately - explore the relationship?

- Weight loss - previously no energy to exercise and potentially explore diet to enhance weight loss which may reduce PAP pressure.

- Education around normal sleep and aging - along with what happens when OSA is left untreated.

- Fear of the treatment and fear of the consequences of not treating the sleep disorder.

- Need for regular follow-ups. 


\section{REFERENCES}

1. Heinzer R, Vat $S$, Marques-Vidal $P$, et al. Prevalence of sleep-disordered breathing in the general population: the HypnoLaus study. Lancet Respir Med. 2015;3(4):310-318.

2. Benjafield AV, Ayas NT, Eastwood PR, et al. Estimation of the global prevalence and burden of obstructive sleep apnoea: a literature-based analysis. The Lancet Respiratory Medicine. 2019;7(8):687-698.

3. Ancoli-Israel S, Kripke DF, Klauber MR, Mason WJ, Fell R, Kaplan O. Sleep-disordered breathing in community-dwelling elderly. Sleep. 1991;14(6):486-495.

4. Wickwire EM, Tom SE, Vadlamani A, et al. Older adult US Medicare beneficiaries with untreated obstructive sleep apnea are heavier users of health care than matched control patients. J Clin Sleep Med. 2020;16(1):81-89.

5. Gaspar LS, Álvaro AR, Moita J, Cavadas C. Obstructive sleep apnea and hallmarks of aging. Trends in molecular medicine. 2017;23(8):675-692.

6. Ding $Q$, Kryger $M$. Greater health care utilization and cost associated with untreated sleep apnea. J Clin Sleep Med. 2020;16(1):5-6.

7. Sullivan C, Issa F, al MB-Je. Reversal of obstructive sleep apnoea by continuous positive airway pressure applied through the nares. Lancet. 1981;1:862-865.

8. McDaid C, Griffin S, Weatherly $\mathrm{H}$, et al. Continuous positive airway pressure devices for the treatment of obstructive sleep apnoea-hypopnoea syndrome: a systematic review and economic analysis. Health technology assessment (Winchester, England). 2009;13(4):iii-iv, xixiv, 1-119, 143-274.

9. Drager LF, McEvoy RD, Barbe F, Lorenzi-Filho G, Redline S. Sleep apnea and cardiovascular disease: lessons from recent trials and need for team science. Circulation. 2017;136(19):18401850.

10. McEvoy RD, Antic NA, Heeley E, et al. CPAP for prevention of cardiovascular events in obstructive sleep apnea. New England Journal of Medicine. 2016;375(10):919-931.

11. Javaheri S, Martinez-Garcia MA, Campos-Rodriguez F. CPAP Treatment and Cardiovascular Prevention: We Need to Change the Design and Implementation of Our Trials. Chest. 2019;156(3):431-437.

12. Javaheri S, Martinez-Garcia MA, Campos-Rodriguez F. CPAP Treatment and Cardiovascular Prevention. 2019.

13. Weaver TE. Novel Aspects of CPAP Treatment and Interventions to Improve CPAP Adherence. Journal of Clinical Medicine. 2019;8(12):2220.

14. Antic NA, Catcheside P, Buchan C, et al. The effect of CPAP in normalizing daytime sleepiness, quality of life, and neurocognitive function in patients with moderate to severe OSA. Sleep. 2011;34(1):111-119.

15. Peppard P, Szklo-Coxe M, Hla K, Young T. Longitudinal Association of sleep-related breathing disorder and depression. Archives of Internal Medicine. 2006;166:1709-1715.

16. Weaver T, Maislin G, Dinges D, et al. Relationship between hours of CPAP use and achieving normal levels of sleepiness and daily functioning. Sleep. 2007;30:711-719.

17. Chaiard J, Weaver TE. Update on Research and Practices in Major Sleep Disorders: Part I. Obstructive Sleep Apnea Syndrome. Journal of Nursing Scholarship. 2019;51(5):500-508. 
18. Jackson ML, McEvoy RD, Banks S, Barnes M. Neurobehavioral impairment and CPAP treatment response in mild-moderate obstructive sleep apnea. J Clin Sleep Med. 2018;14(01):47-56.

19. Stradling JR, Davies RJ. Is more NCPAP better? Sleep. 2000;23 Suppl 4:S150-153.

20. Antic NA, Catcheside P, Buchan C, et al. The effect of CPAP in normalizing daytime sleepiness, quality of life, and neurocognitive function in patients with moderate to severe OSA. Sleep. 2011;34(1):111-119.

21. Zhou J, Camacho M, Tang X, Kushida CA. A review of neurocognitive function and obstructive sleep apnea with or without daytime sleepiness. Sleep Med. 2016;23:99-108.

22. Campos-Rodriguez F, Pena-Grinan N, Reyes-Nunez N, et al. Mortality in obstructive sleep apnea-hypopnea patients treated with positive airway pressure. Chest. 2005;128(2):624-633.

23. Engleman H, Wild M. Improving CPAP use by patients with the sleep apnea/hypopnea syndrome (SAHS). Sleep Medicine Reviews. 2003;7:81-99.

24. Budhiraja R, Parthasarathy $\mathrm{S}$, Drake $\mathrm{CL}$, et al. Early CPAP use identifies subsequent adherence to CPAP therapy. Sleep. 2007;30(3):320-324.

25. Kribbs NB, Pack Al, Kline LR, et al. Objective measurement of patterns of nasal CPAP use by patients with obstructive sleep apnea. American Review of Respiratory Disease. 1993;147(4):887-895.

26. Engleman HM, Martin SE, Douglas NJ. Compliance with CPAP therapy in patients with the sleep apnoea/hypopnoea syndrome. Thorax. 1994;49(3):263-266.

27. Reeves-Hoche MK, Meck R, Zwillich CW. Nasal CPAP: an objective evaluation of patient compliance. American journal of respiratory and critical care medicine. 1994;149(1):149-154.

28. Mehrtash M, Bakker J, Ayas N. Predictors of continuous positive airway pressure adherence in patients with obstructive sleep apnea. Lung. 2019;197(2):115-121.

29. Inoue A, Chiba S, Matsuura K, Osafune H, Capasso R, Wada K. Nasal function and CPAP compliance. Auris Nasus Larynx. 2019;46(4):548-558.

30. Bailly S, Destors $M$, Grillet $Y$, et al. Obstructive sleep apnea: a cluster analysis at time of diagnosis. PLOS ONE. 2016;11(6):e0157318.

31. Gagnadoux F, Le Vaillant M, Paris A, et al. Relationship between OSA clinical phenotypes and CPAP treatment outcomes. Chest. 2016;149(1):288-290.

32. Pien GW, Ye L, Keenan BT, et al. Changing faces of obstructive sleep apnea: treatment effects by cluster designation in the Icelandic Sleep Apnea Cohort. Sleep. 2018;41(3):zs×201.

33. Bachour A, Vitikainen P, Maasilta P. Rates of initial acceptance of PAP masks and outcomes of mask switching. Sleep Breathing. 2015:1-6.

34. Krakow B, Melendrez D, Haynes P. Integrating psychosocial and biomedical CPAP adherence models. A commentary on: "Improving CPAP use by patients with the sleep apnea/hypopnea syndrome (SAHS)" (HM Engleman \& MR Wild). Sleep Med Rev. 2003;7(5):441-444.

35. Lebret M, Martinot JB, Arnol N, et al. Factors Contributing to Unintentional Leak During CPAP Treatment: A Systematic Review. Chest. 2017;151(3):707-719.

36. Lettieri CJ, Williams SG, Collen JF, Wickwire EM. Treatment of Obstructive Sleep Apnea: Achieving Adherence to Positive Airway Pressure Treatment and Dealing with Complications. Sleep Med Clin. 2017;12(4):551-564.

37. Chasens ER, Pack Al, Maislin G, Dinges DF, Weaver TE. Claustrophobia and adherence to CPAP treatment. West J Nurs Res. 2005;27(3):307-321. 
38. Edmonds JC, Yang H, King TS, Sawyer DA, Rizzo A, Sawyer AM. Claustrophobic tendencies and continuous positive airway pressure therapy non-adherence in adults with obstructive sleep apnea. Heart Lung. 2015;44(2):100-106.

39. Anderson FE, Kingshott RN, Taylor DR, Jones DR, Kline LR, Whyte KF. A randomized crossover efficacy trial of oral CPAP (Oracle) compared with nasal CPAP in the management of obstructive sleep apnea. Sleep. 2003;26(6):721-726.

40. Rowland S, Aiyappan V, Hennessy C, et al. Comparing the efficacy, mask leak, patient adherence, and patient preference of three different CPAP interfaces to treat moderatesevere obstructive sleep apnea. J Clin Sleep Med. 2018;14(1):101-108.

41. Chai CL, Pathinathan A, Smith B. Continuous positive airway pressure delivery interfaces for obstructive sleep apnoea. Cochrane Database of Systematic Reviews. 2006(4).

42. Boyer L, Philippe C, Covali-Noroc A, et al. OSA treatment with CPAP: Randomized crossover study comparing tolerance and efficacy with and without humidification by ThermoSmart. Clin Respir J. 2019;13(6):384-390.

43. Massie CA, Hart RW, Peralez K, Richards GN. Effects of humidification on nasal symptoms and compliance in sleep apnea patients using continuous positive airway pressure. Chest. 1999;116(2):403-408.

44. Bakker JP, Marshall NS. Flexible pressure delivery modification of continuous positive airway pressure for obstructive sleep apnea does not improve compliance with therapy: Systematic review and meta-analysis. Chest. 2011;139(6):1322-1330.

45. Kushida CA, Berry RB, Blau A, et al. Positive airway pressure initiation: A randomized controlled trial to assess the impact of therapy mode and titration process on efficacy, adherence, and outcomes. Sleep. 2011;34(8):1083-1092.

46. Kennedy B, Lasserson TJ, Wozniak DR, Smith I. Pressure modification or humidification for improving usage of continuous positive airway pressure machines in adults with obstructive sleep apnoea. Cochrane Database of Systematic Reviews. 2019;2019(12).

47. Goh KJ, Soh RY, Leow LC, et al. Choosing the right mask for your Asian patient with sleep apnoea: A randomized, crossover trial of CPAP interfaces. Respirology. 2019;24(3):278-285.

48. Ma Z, Drinnan M, Hyde P, Munguia J. Mask interface for continuous positive airway pressure therapy: selection and design considerations. Expert Review of Medical Devices. 2018;15(10):725-733.

49. Craig P, Dieppe P, Macintyre S, Michie S, Nazareth I, Petticrew M. Developing and evaluating complex interventions: the new Medical Research Council guidance. BMJ. 2008;337:a1655.

50. Smith CE, Mayer LS, Metsker C, et al. Continuous positive airway pressure: patients' and caregivers' learning needs and barriers to use. Heart Lung. 1998;27(2):99-108.

51. Brostrom A, Johansson P, Albers J, Wiberg J, Svanborg E, Fridlund B. 6-month CPAP-treatment in a young male patient with severe obstructive sleep apnoea syndrome - a case study from the couple's perspective. Eur J Cardiovasc Nurs. 2008;7(2):103-112.

52. Ayow TM, Paquet F, Dallaire J, Purden M, Champagne KA. Factors influencing the use and nonuse of continuous positive airway pressure therapy: a comparative case study. Rehabil Nurs. 2009;34(6):230-236.

53. Zarhin D, Oksenberg A. Ambivalent Adherence and Nonadherence to Continuous Positive Airway Pressure Devices: A Qualitative Study. J Clin Sleep Med. 2017;13(12):1375-1384. 
54. Brostrom A, Nilsen $P$, Johansson $P$, et al. Putative facilitators and barriers for adherence to CPAP treatment in patients with obstructive sleep apnea syndrome: a qualitative content analysis. Sleep Med. 2010;11(2):126-130.

55. Dickerson SS, Akhu-Zaheya L. Life changes in individuals diagnosed with sleep apnea while accommodating to continuous positive airway pressure (CPAP) devices. Rehabil Nurs. 2007;32(6):241-250.

56. Luyster FS, Dunbar-Jacob J, Aloia MS, Martire LM, Buysse DJ, Strollo PJ. Patient and Partner Experiences With Obstructive Sleep Apnea and CPAP Treatment: A Qualitative Analysis. Behav Sleep Med. 2016;14(1):67-84.

57. Aalaei S, Rezaeitalab F, Tabesh H, et al. Factors Affecting Patients' Adherence to Continuous Positive Airway Pressure Therapy for Obstructive Sleep Apnea Disorder: A Multi-Method Approach. Iranian Journal of Medical Sciences. 2019:-.

58. Baron KG, Gunn HE, Wolfe LF, Zee PC. Relationships and CPAP adherence among women with obstructive sleep apnea. Sleep Science and Practice. 2017;1(1):10.

59. Ward K, Gott M, Hoare K. Mastering Treatment for Sleep Apnoea: The Grounded Theory of Bargaining and Balancing Life With Continuous Positive Airway Pressure (CPAP), in the Context of Decisional Conflict and Change Theories. 2019. 2019;20(3).

60. Sawyer AM, Deatrick JA, Kuna ST, Weaver TE. Differences in perceptions of the diagnosis and treatment of obstructive sleep apnea and continuous positive airway pressure therapy among adherers and nonadherers. Qual Health Res. 2010;20(7):873-892.

61. Crawford MR, Vallieres A. The dark side of adherence-a commentary on Palm et al. (2018) factors influencing adherence to continuous positive airway pressure treatment in obstructive sleep apnea and mortality associated with treatment failure - A national registry-based cohort study. Sleep Med. 2018 Jul 17; 51: 85-91. Sleep Med. 2019;59:96.

62. Wozniak DR, Lasserson TJ, Smith I. Educational, supportive and behavioural interventions to improve usage of continuous positive airway pressure machines in adults with obstructive sleep apnoea. The Cochrane database of systematic reviews. 2014;1:Cd007736.

63. Bandura A. Social learning theory. Englewood Cliffs, NJ: Prentice Hall; 1977.

64. Bandura A. Human agency in social cognitive theory. The American psychologist. 1989;44(9):1175-1184.

65. Aloia M, Arendt J, Stepnowski C. Predicting treatment adherence in obstructive sleep apnea using principles of behaviour change. Journal of Clinical Sleep Medicine. 2005;1:346 - 353.

66. Stepnowsky C, Marler M, Ancoli-Israel S. Determinants of nasal CPAP compliance. Sleep Med. 2002;3:239-247.

67. Stepnowsky CJ, Jr., Bardwell WA, Moore PJ, Ancoli-Israel S, Dimsdale JE. Psychologic correlates of compliance with continuous positive airway pressure. Sleep. 2002;25(7):758-762.

68. Weaver T, Maislin G, Dinges $D$, et al. Self efficacy in sleep apnea: Instrument development and patient perceptions of obstructive sleep apnea risk, treatment benefit and volition to use continuous positive airway pressure. Sleep. 2003;26:727-732.

69. Sawyer AM, Canamucio A, Moriarty H, Weaver TE, Richards KC, Kuna ST. Do cognitive perceptions influence CPAP use? Patient Educ Couns. 2011;85(1):85-91.

70. Olsen S, Smith S, Oei T, Douglas J. Health belief and model predicts adherence to CPAP before experience with CPAP. Eur Respir J. 2008;32:710-717. 
71. Richards D, Bartlett D, Wong K, Malouff J, Grunstein R. Increased adherence to CPAP with a group cognitive behavioural treatment intervention: A randomized trial. Sleep. 2007;30:635640.

72. Bartlett D, Wong K, Richards D, et al. Increasing adherence to obstructive sleep apnea treatment with a group social cognitive therapy treatment intervention: a randomized trial. Sleep. 2013;36(11):1647-1654.

73. Saconi B, Yang H, Watach AJ, Sawyer AM. Coping Processes, Self-Efficacy, and CPAP Use in Adults With Obstructive Sleep Apnea. Behav Sleep Med. 2020;18(1):68-80.

74. Baron KG, Berg CA, Czajkowski LA, Smith TW, Gunn HE, Jones CR. Self-efficacy contributes to individual differences in subjective improvements using CPAP. Sleep \& breathing $=$ Schlaf \& Atmung. 2011;15(3):599-606.

75. Aloia MS, Di Dio L, Ilniczky N, Perlis ML, Greenblatt DW, Giles DE. Improving compliance with nasal CPAP and vigilance in older adults with OAHS. Sleep \& breathing $=$ Schlaf \& Atmung. 2001;5(1):13-21.

76. Aloia $\mathrm{M}$, Smith $\mathrm{K}$, Arendt J, et al. Brief behavioral therapies reduce early positive airway pressure discontinuation rates in sleep apnea syndrom: Preliminary findings. Behavorial Sleep Medicine. 2007;5(2):89-104.

77. Olsen S, Smith S, Oei T, Douglas J. Cues to starting CPAP in obstructive sleep apnea: Development and validation of the cues to CPAP use questionnaire. J Clin Sleep Med. 2010;6:229-237.

78. Olsen S, Smith SS, Oei TP, Douglas J. Motivational interviewing (MINT) improves continuous positive airway pressure (CPAP) acceptance and adherence: a randomized controlled trial. Journal of consulting and clinical psychology. 2012;80(1):151-163.

79. Aloia MS, Arnedt JT, Strand M, Millman RP, Borrelli B. Motivational enhancement to improve adherence to positive airway pressure in patients with obstructive sleep apnea: a randomized controlled trial. Sleep. 2013;36(11):1655-1662.

80. Sawyer AM, King TS, Hanlon A, et al. Risk assessment for CPAP nonadherence in adults with newly diagnosed obstructive sleep apnea: preliminary testing of the Index for Nonadherence to PAP (I-NAP). Sleep Breathing. 2014:1-9.

81. Lai AY, Fong DY, Lam JC, Weaver TE, Ip MS. The efficacy of a brief motivational enhancement education program on CPAP adherence in OSA: a randomized controlled trial. Chest. 2014;146(3):600-610.

82. Deng $T$, Wang $Y$, Sun $M$, Chen B. Stage-matched intervention for adherence to CPAP in patients with obstructive sleep apnea: a randomized controlled trial. Sleep \& breathing $=$ Schlaf \& Atmung. 2013;17(2):791-801.

83. Cvengros JA, Rodríguez VM, Snyder S, Hood MM, Crawford M, Park M. An adaptive treatment to improve positive airway pressure (PAP) adherence in patients with obstructive sleep apnea: a proof of concept trial. Behav Sleep Med. 2017;15(5):345-360.

84. Epstein L, Kristo D, Strollo PJ, Jr., et al. Clinical guideline for the evaluation, management and long-term care of obstructive sleep apnea in adults. J Clin Sleep Med. 2009;5(3):263-276.

85. Sawyer AM, Gooneratne NS, Marcus CL, Ofer D, Richards KC, Weaver TE. A systematic review of CPAP adherence across age groups: clinical and empiric insights for developing CPAP adherence interventions. Sleep Med Rev. 2011;15(6):343-356. 
86. Hoy C, Vennelle R, Kingshott R, Engleman H, Douglas N. Can intensive support improve continuous positive airway pressure use in patients with the sleep apnea/hypopnea syndrome? Am J Respir Crit Care Med. 1999;159:1096-1100.

87. Delanote I, Borzée P, Belge C, Buyse B, Testelmans D. Adherence to cpap therapy: comparing the effect of three educational approaches in patients with obstructive sleep apnoea. The clinical respiratory journal. 2018;12(1):91-96.

88. Stepnowsky C, Sarmiento KF, Amdur A. Weaving the Internet of Sleep: The Future of PatientCentric Collaborative Sleep Health Management Using Web-Based Platforms. Sleep. 2015;38(8):1157-1158.

89. Sedkaoui K, Leseux L, Pontier S, et al. Efficiency of a phone coaching program on adherence to continuous positive airway pressure in sleep apnea hypopnea syndrome: a randomized trial. BMC Pulm Med. 2015;15:102.

90. Lo Bue A, Salvaggio A, Isidoro SI, Romano S, Marrone O, Insalaco G. Usefulness of reinforcing interventions on continuous positive airway pressure compliance. BMC Pulm Med. 2014;14:78.

91. Soares Pires F, Drummond M, Marinho A, et al. Effectiveness of a group education session on adherence with APAP in obstructive sleep apnea--a randomized controlled study. Sleep \& breathing $=$ Schlaf \& Atmung. 2013;17(3):993-1001.

92. Sin DD, Mayers I, Man GC, Pawluk L. Long-term compliance rates to continuous positive airway pressure in obstructive sleep apnea: a population-based study. Chest. 2002;121(2):430-435.

93. Bouloukaki I, Giannadaki K, Mermigkis C, et al. Intensive versus standard follow-up to improve continuous positive airway pressure compliance. Eur Respir J. 2014;44(5):1262-1274.

94. Chen X, Chen W, Hu W, Huang K, Huang J, Zhou Y. Nurse-led intensive interventions improve adherence to continuous positive airway pressure therapy and quality of life in obstructive sleep apnea patients. Patient Prefer Adherence. 2015;9:1707-1713.

95. Parthasarathy S, Wendel C, Haynes PL, Atwood C, Kuna S. A pilot study of CPAP adherence promotion by peer buddies with sleep apnea. J Clin Sleep Med. 2013;9(6):543-550.

96. Lewis KE, Seale L, Bartle IE, Watkins AJ, Ebden P. Early predictors of CPAP use for the treatment of obstructive sleep apnea. Sleep. 2004;27(1):134-138.

97. Baron KG, Smith TW, Berg CA, Czajkowski LA, Gunn H, Jones CR. Spousal involvement in CPAP adherence among patients with obstructive sleep apnea. Sleep Breathing. 2011;15(3):525534.

98. McArdle N, Kingshott R, Engleman H, Mackay T, Douglas N. Partners of patients with sleep apnoea/hypopnoea syndrome: effect of CPAP treatment on sleep quantity and quality of life. Thorax. 2001;56:513-518.

99. Ye L, Malhotra A, Kayser K, et al. Spousal involvement and CPAP adherence: A dyadic perspective. Sleep Med Rev. 2015;19:67-74.

100. Golay A, Girard A, Grandin S, et al. A new educational program for patients suffering from sleep apnea syndrome. Patient education and counseling. 2006;60(2):220-227.

101. Sawyer AM, King TS, Sawyer DA, Rizzo A. Is Inconsistent Pre-Treatment Bedtime Related to CPAP Non-Adherence? Research in nursing \& health. 2014;37(6):504-511.

102. D'Rozario AL, Galgut Y, Bartlett DJ. An Update on Behavioural Interventions for Improving Adherence with Continuous Positive Airway Pressure in Adults. Current Sleep Medicine Reports. 2016;2(3):166-179. 
103. Bakker JP, Wang R, Weng J, et al. Motivational enhancement for increasing adherence to CPAP: A randomized controlled trial. Chest. 2016.

104. Hoet F, Libert W, Sanida C, Van den Broecke S, Bruyneel AV, Bruyneel M. Telemonitoring in continuous positive airway pressure-treated patients improves delay to first intervention and early compliance: a randomized trial. Sleep Med. 2017;39:77-83.

105. Hwang D, Chang JW, Benjafield AV, et al. Effect of telemedicine education and telemonitoring on continuous positive airway pressure adherence. The tele-OSA randomized trial. American journal of respiratory and critical care medicine. 2018;197(1):117-126.

106. Guralnick AS, Balachandran JS, Szutenbach S, et al. Educational video to improve CPAP use in patients with obstructive sleep apnoea at risk for poor adherence: a randomised controlled trial. Thorax. 2017;72(12):1132-1139.

107. Munafo D, Hevener W, Crocker M, Willes L, Sridasome S, Muhsin M. A telehealth program for CPAP adherence reduces labor and yields similar adherence and efficacy when compared to standard of care. Sleep \& breathing = Schlaf \& Atmung. 2016.

108. Nilius G, Schroeder M, Domanski U, Tietze A, Schafer T, Franke KJ. Telemedicine Improves Continuous Positive Airway Pressure Adherence in Stroke Patients with Obstructive Sleep Apnea in a Randomized Trial. Respiration. 2019;98(5):410-420.

109. Pengo MF, Czaban M, Berry MP, et al. The effect of positive and negative message framing on short term continuous positive airway pressure compliance in patients with obstructive sleep apnea. J Thorac Dis. 2018;10:S160-S169.

110. Luyster FS, Aloia MS, Buysse DJ, et al. A Couples-Oriented Intervention for Positive Airway Pressure Therapy Adherence: A Pilot Study of Obstructive Sleep Apnea Patients and Their Partners. Behav Sleep Med. 2019;17(5):561-572.

111. Sawyer AM, King TS, Weaver TE, et al. A Tailored Intervention for PAP Adherence: The SCIPPA Trial. Behav Sleep Med. 2019;17(1):49-69.

112. Shapiro AL. Effect of the CPAP-SAVER Intervention on Adherence. Clin Nurs Res. 2019.

113. Sweetman A, Lack L, Catcheside PG, et al. Cognitive and behavioral therapy for insomnia increases the use of continuous positive airway pressure therapy in obstructive sleep apnea participants with comorbid insomnia: a randomized clinical trial. Sleep. 2019;42(12).

114. Turino C, De Batlle J, Woehrle H, et al. Management of continuous positive airway pressure treatment compliance using telemonitoring in obstructive sleep apnoea. Eur Respir J. 2017;49(2).

115. Fernandes M, Antunes C, Martinho C, et al. Evaluation of telemonitoring of continuous positive airway pressure therapy in obstructive sleep apnoea syndrome: TELEPAP pilot study. J Telemed Telecare. 2019.

116. Pépin J-L, Jullian-Desayes $I$, Sapène $M$, et al. Multimodal remote monitoring of high cardiovascular risk patients with OSA initiating CPAP: a randomized trial. Chest. 2019;155(4):730-739.

117. Zhang $\mathrm{Y}$, Ren R, Lei $\mathrm{F}$, et al. Worldwide and regional prevalence rates of co-occurrence of insomnia and insomnia symptoms with obstructive sleep apnea: A systematic review and meta-analysis. Sleep Med Rev. 2019;45:1-17.

118. Sweetman A, Lack L, Catcheside PG, et al. Cognitive and behavioral therapy for insomnia increases the use of continuous positive airway pressure therapy in obstructive sleep apnea participants with comorbid insomnia: a randomized clinical trial. Sleep. 2019;42(12):zsz178. 
TABLE 1: AN UPDATE ON BEHAVIOURAL INTERVENTIONS FOR IMPROVING ADHERENCE WITH POSITIVE AIRWAY PRESSURE IN ADULTS

\begin{tabular}{|c|c|c|c|c|}
\hline Author & $\begin{array}{ll}\text { Study Design } \\
\text { 1. } \\
\text { 2ype } \\
\text { Intervention Group } \\
\text { (IG) } \\
\text { 3. } \\
\text { 4. } \\
\text { Assentrol Group (CG) } \\
\text { point(s) }\end{array}$ & Subjects & Intervention Strategy and Description & Impact on CPAP Adherence \\
\hline
\end{tabular}




\begin{tabular}{|c|c|c|c|c|}
\hline $\begin{array}{l}\text { Fernandes } \\
\text { et al. } 2019 \\
115\end{array}$ & $\begin{array}{l}\text { 1. Technological } \\
\text { intervention } \\
\text { 2. Two intervention } \\
\text { arms: } \\
\text { a. IG1: Phone- } \\
\text { call support } \\
\text { b. IG2: } \\
\text { Telemonitoring } \\
\text { 3. Usual care } \\
\text { 4. 4-week follow-up }\end{array}$ & $\begin{array}{l}51 \text { patients with } \\
\text { moderate to severe } \\
\text { OSA } \\
(\mathrm{IG} 1: \mathrm{n}=18 ; \mathrm{IG} 2: \\
\mathrm{n}=12 ; \mathrm{CG}: \mathrm{n}=21)\end{array}$ & $\begin{array}{l}\text { IG1: Patients received regular phone calls by } \\
\text { study staff over a 4-week period in which } \\
\text { staff assessed patients self-reported } \\
\text { adherence and addressed issues relating to } \\
\text { patient's clinical status/treatment. Each call } \\
\text { lasted approximately } 7 \text { minutes. The number } \\
\text { of calls made to each patient ranged from } 4-7 \\
\text { (M=4.4) over the } 4 \text {-week period with the } \\
\text { frequency determined by the study staff's } \\
\text { perceptions of patient needs. } \\
\text { IG2: Patient CPAP devices were fitted with a } \\
\text { telemonitoring unit which enabled CPAP } \\
\text { data to be collected on a daily cycle and } \\
\text { transmitted wirelessly to a secured web } \\
\text { portal accessible by study staff. If low daily } \\
\text { compliance was detected, a management } \\
\text { CPAP protocol was activated by a respiratory } \\
\text { therapist. This protocol was based on an } \\
\text { algorithm in order to detect and correct } \\
\text { adverse effects and reinforce CPAP } \\
\text { compliance in a timely manner. If necessary, } \\
\text { a provider technician performed home visits } \\
\text { and resolved issues (e.g. changing interfaces, } \\
\text { placement of humidifier). }\end{array}$ & $\begin{array}{l}\text { 4-week: No significant } \\
\text { differences found in mean daily } \\
\text { CPAP use between IG1, IG } 2 \text { and } \\
\text { CG }(3.9 \pm 2.6 \text { vs. } 5.0 \pm 1.8 \text { vs. } \\
5.1 \pm 2.5 \mathrm{~h} \text { /day, respectively, } \\
\text { p }=0.296)\end{array}$ \\
\hline
\end{tabular}




\begin{tabular}{|c|c|c|c|c|}
\hline $\begin{array}{l}\text { Guralnick } \\
\text { et al. } 2017 \\
106\end{array}$ & $\begin{array}{l}\text { 1. Educational } \\
\text { intervention } \\
\text { 2. Brief educational } \\
\text { video } \\
\text { 3. Usual Care } \\
\text { 4. 30-day follow-up }\end{array}$ & $\begin{array}{l}212 \text { newly } \\
\text { diagnosed OSA } \\
\text { patients } \\
(\mathrm{IG}: \mathrm{n}=99 ; \mathrm{CG}: \\
\mathrm{n}=113)\end{array}$ & $\begin{array}{l}\text { Patients watched a 4-minute educational } \\
\text { video on consequences of untreated OSA and } \\
\text { the importance/benefits of CPAP prior to } \\
\text { undertaking a polysomnogram (PSG) for } \\
\text { OSA diagnosis and receiving CPAP within } 2 \\
\text { weeks of the PSG. }\end{array}$ & $\begin{array}{l}\text { 30-days: No significant } \\
\text { differences found between IG } \\
\text { and CG on: mean daily CPAP } \\
\text { use }(3.3 \pm 2.5 \text { vs. } 3.5 \pm 2.2 \mathrm{~h} / \text { night, } \\
\mathrm{p}=.44) ; \text { number of days used } \\
(18.7 \pm 10.6 \text { vs. } 21.5 \pm 9.2, \mathrm{p}=.045) \text {; } \\
\text { percentage of days used } \geq 4 \mathrm{~h} \\
(44.5 \pm 35.4 \text { vs. } 47.1 \pm 34.6 \% \text {, } \\
\mathrm{p}=.58) \text { and Medicare CPAP } \\
\text { adherence rates ( } 32.3 \text { vs. } 31.9 \% \text {, } \\
p=1) .\end{array}$ \\
\hline $\begin{array}{l}\text { Hoet et al. } \\
(2017){ }^{104}\end{array}$ & $\begin{array}{l}\text { 1. Technological } \\
\text { intervention } \\
\text { 2. Telemonitoring } \\
\text { 3. Usual care } \\
\text { 4. } 3 \text { month follow-up }\end{array}$ & $\begin{array}{l}46 \text { newly } \\
\text { diagnosed OSA } \\
\text { patients } \\
(\mathrm{IG}: \mathrm{n}=23 ; \mathrm{CG} \text { : } \\
\mathrm{n}=23)\end{array}$ & $\begin{array}{l}\text { Patient CPAP devices were linked to a } \\
\text { telemonitoring unit which transmitted patient } \\
\text { CPAP data (e.g. daily report of usage, mask } \\
\text { leaks, CPAP pressure, and residual apnea } \\
\text { hypopnea index) to practitioners via a web } \\
\text { portal. Sleep laboratory technical staff } \\
\text { connected to this web portal and analysed } \\
\text { patient's data twice per week. If problems } \\
\text { were identified (e.g. air leaks }>50 \mathrm{~L} / \mathrm{min} \text {, } \\
\text { residual AHI }>10 / \mathrm{h} \text {, or CPAP use }<3 \mathrm{~h} \text { on } 3 \\
\text { consecutive days) patients were called to } \\
\text { arrange a visit with staff to resolve. }\end{array}$ & $\begin{array}{l}3 \text { month: Average CPAP } \\
\text { compliance was significantly } \\
\text { better for the IG compared to CG } \\
\text { ( } 5.7 \pm 1.6 \text { vs. } 4.2 \pm 1.9 \mathrm{~h} / \text { night, } \\
\text { respectively, } \mathrm{p}=0.018) \\
\text { In all, } 64 \% \text { of } \mathrm{CG} \text { and } 82 \% \text { of } \mathrm{IG} \\
\text { patients were considered to be } \\
\text { adherent (i.e. using CPAP for } \geq 4 \\
\text { h/night) at } 3 \text { months ( }=0.35 \text { ). In } \\
\text { adherent patients, longer nightly } \\
\text { use of CPAP was observed in the } \\
\text { IG at } 3 \text { months compared to CG } \\
(6.2 \text { [4-8.1] vs. } 5.2 \text { [ } 4-7.5] \\
\text { h/night, respectively, } p=0.027 \text { ). }\end{array}$ \\
\hline
\end{tabular}




\begin{tabular}{|c|c|c|c|c|}
\hline $\begin{array}{l}\text { Hwang et } \\
\text { al. } 2018 \\
105\end{array}$ & 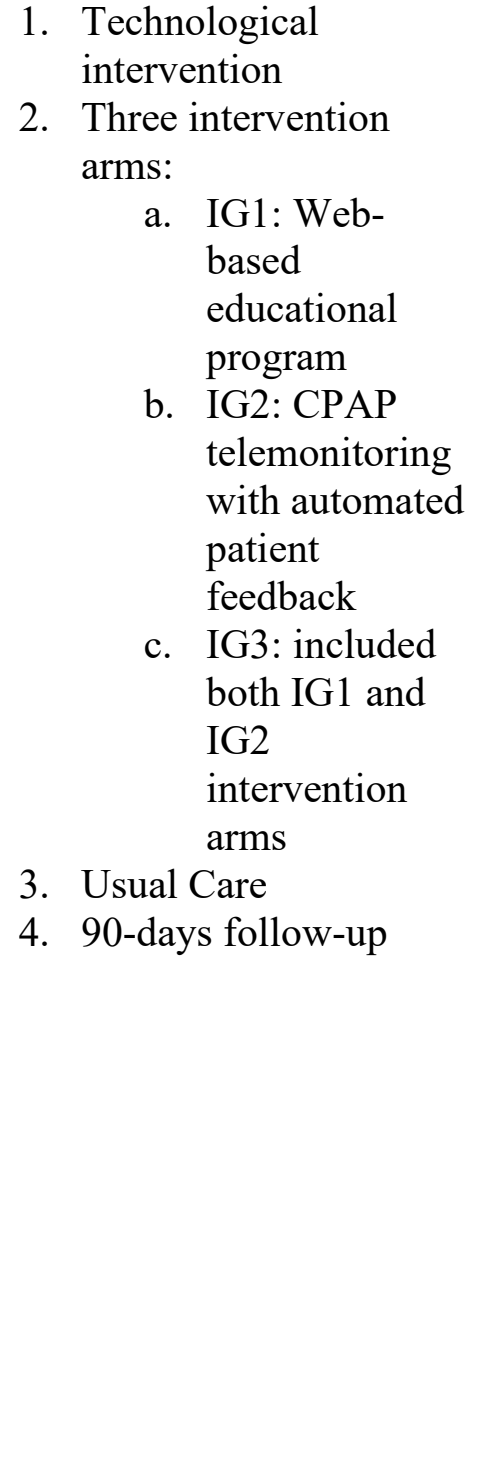 & $\begin{array}{l}556 \text { newly } \\
\text { diagnosed OSA } \\
\text { patients } \\
\text { (IG1: } \mathrm{n}=164 ; \mathrm{IG} 2: \\
\mathrm{n}=125 ; \mathrm{IG} 3: \\
\mathrm{n}=138 ; \mathrm{CG}: \\
\mathrm{n}=129)\end{array}$ & $\begin{array}{l}\text { IG1: Emailed link to the OSA educational } \\
\text { program and received an appointment } \\
\text { reminder call } 2 \text { weeks before their Home } \\
\text { Sleep Apnea Testing (HSAT) class. The } \\
\text { OSA program included educational videos } \\
\text { about the pathophysiology of OSA, health- } \\
\text { related risks of OSA, an introduction to } \\
\text { CPAP therapy, and assessment process } \\
\text { details. Patients diagnosed with OSA were } \\
\text { emailed a link to the CPAP educational } \\
\text { program during their 1-week trial of CPAP. } \\
\text { It outlined information on how to properly } \\
\text { use CPAP, potential benefits of treatment on } \\
\text { health and daytime vigilance, methods of } \\
\text { acclimating, and equipment care instructions. } \\
\text { Both educational programs were self-paced, } \\
\text { interactive and typically lasted } 15 \text { minutes. } \\
\text { IG2: Patient CPAP devices were linked to a } \\
\text { web-based application (U-Sleep; ResMed } \\
\text { Corp) which receives and interprets device } \\
\text { data and provides automated feedback } \\
\text { through messages via the patients preferred } \\
\text { method (i.e. text messaging, e-mail, phone } \\
\text { call, or a combination). For example, if } \\
\text { CPAP usage thresholds were met, a message } \\
\text { was automatically sent to the patient } \\
\text { providing encouragement to improve use or } \\
\text { positively reinforcing successful adherence. } \\
\text { IG3: included both IG1 and IG } 2 \text { components } \\
\text { Inithe }\end{array}$ & $\begin{array}{l}90 \text { days: Average daily CPAP } \\
\text { use was significantly higher in } \\
\text { the IG2 and IG3 groups } \\
\text { compared to CG ( } 4.4 \pm 2.2 \text {, and } \\
4.8 \pm 2.3 \text { vs. } 3.8 \pm 2.5 \mathrm{~h} / \text { day, } \\
\text { respectively; } \mathrm{p}=0.0002 \text { for both), } \\
\text { but not for IG1 ( } 4.0 \pm 2.4 \text { vs. } \\
3.8 \pm 2.5 \mathrm{~h} / \text { day, } \mathrm{p}=0.10) \text {. The IG2 } \\
\text { and IG3 groups also showed a } \\
\text { significant increase, compared } \\
\text { with CG, in the proportion of } \\
\text { days that CPAP was used ( } 76.6 \\
\text { and } 78.3 \% \text { vs. } 64.8 \% ; \mathrm{p}=0.0001 \\
\text { and } \mathrm{p}=0.0004, \text { respectively) and } \\
\text { in Medicare adherence rates } \\
\text { (65.6 and } 73.2 \% \text { vs. } 53.5 \% ; \mathrm{p}= \\
0.003 \text { and } \mathrm{p}=0.001, \\
\text { respectively). No significant } \\
\text { differences found between IG1 } \\
\text { and CG in proportion of days } \\
\text { that CPAP was used ( } 68.6 \text { vs. } \\
64.8 \%, \mathrm{p}=0.28) \text { and in Medicare } \\
\text { adherence rates ( } 61.0 \text { vs. } 53.5 \% \text {, } \\
\mathrm{p}=0.07) .\end{array}$ \\
\hline
\end{tabular}




\begin{tabular}{|c|c|c|c|c|}
\hline $\begin{array}{l}\text { Luyster et } \\
\text { al. } 2019 \\
110 *\end{array}$ & $\begin{array}{l}\text { 1. Pilot; Psychosocial } \\
\text { intervention } \\
\text { 2. Two intervention } \\
\text { arms: } \\
\text { a. IG1: Couples- } \\
\text { orientated } \\
\text { education and } \\
\text { support } \\
\text { b. IG2: Patient } \\
\text { only education } \\
\text { and support } \\
\text { 3. Usual Care } \\
\text { 4. 1- \& 3- months }\end{array}$ & $\begin{array}{l}30 \text { newly } \\
\text { diagnosed OSA } \\
\text { patients and their } \\
\text { partners } \\
\text { (IG1:n=8; } \\
\text { IG2:n=10; } \\
\text { CG:n=12) }\end{array}$ & $\begin{array}{l}\text { IG1: both patient and their partner attended } \\
\text { two 1-hr face-to-face sessions and then each } \\
\text { person independently received a } 20 \text {-min } \\
\text { follow-up telephone call 1-week after the } \\
\text { completion of session } 2 \text {. Both sessions and } \\
\text { telephone calls were conducted by a trained } \\
\text { respiratory therapist. } \\
\text { Session 1: delivered before PAP setup and } \\
\text { included educational videos about OSA and } \\
\text { PAP, a demonstration of PAP, structured } \\
\text { conversations about common and individual } \\
\text { PAP concerns and goal setting with support } \\
\text { of the partner in mind. Session 2: delivered } \\
\text { 1-week after PAP set up and included a } \\
\text { review of patient's data with a focus on } \\
\text { identifying barriers of PAP use and further } \\
\text { goal setting. } \\
\text { Telephone call focused on reviewing goals, } \\
\text { overcoming barriers and tailoring support } \\
\text { from their partner. } \\
\text { IG2: same as IG1 but partners did not } \\
\text { participate. }\end{array}$ & 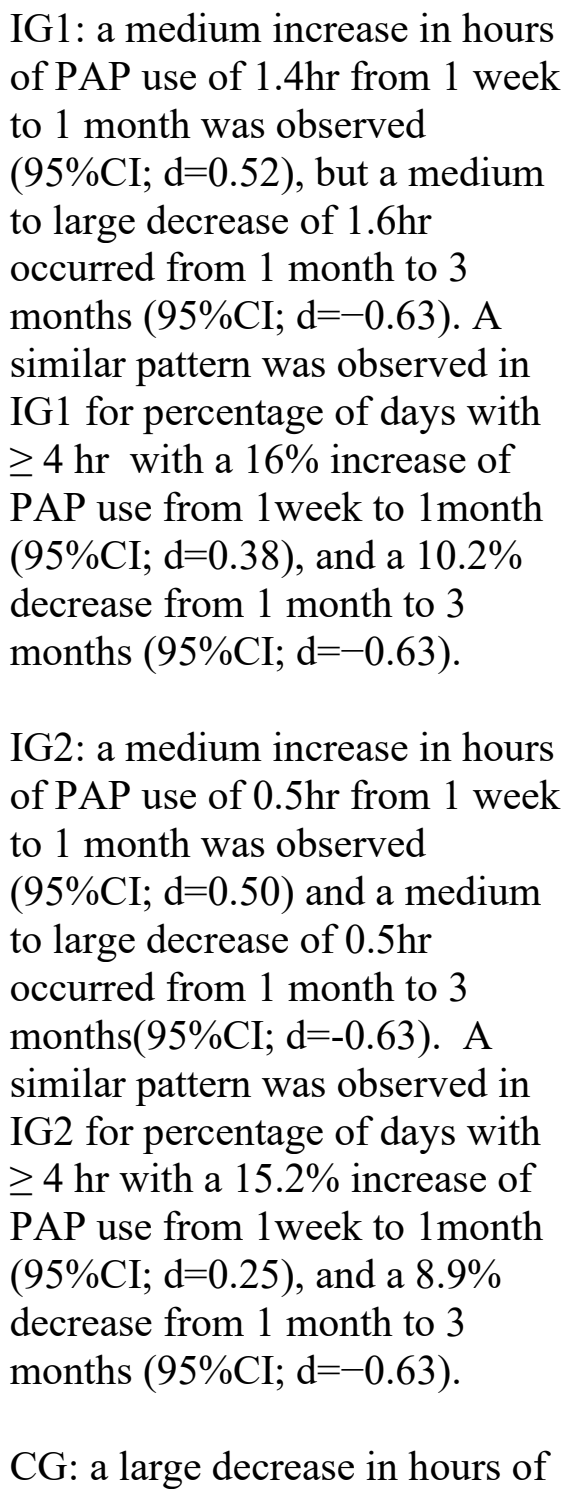 \\
\hline
\end{tabular}




\begin{tabular}{|c|c|c|c|c|}
\hline & & & & $\begin{array}{l}\text { PAP use of } 0.7 \mathrm{hr} \text { was observed } \\
\text { from } 1 \text { week to } 1 \text { month }(95 \% \mathrm{CI} \text {; } \\
\mathrm{d}=0.92) \text { and a small decrease of } \\
0.3 \mathrm{hr} \text { was observed } 1 \text { month to } 3 \\
\text { months }(95 \% \mathrm{CI} ; \mathrm{d}=0.26) . \text { A } \\
\text { similar pattern was observed in } \\
\text { CG for percentage of days with } \geq \\
4 \mathrm{hr} \text { with a } 10.4 \% \text { decrease of } \\
\text { PAP use from } 1 \text { week to } 1 \text { month } \\
(95 \% \mathrm{CI} \text {; } \mathrm{d}=1.38) \text {, and a } 5.2 \% \\
\text { decrease from } 1 \text { month to } 3 \\
\text { months }(95 \% \mathrm{CI} ; \mathrm{d}=-0.30) .\end{array}$ \\
\hline $\begin{array}{l}\text { Munafo et } \\
\text { al. } 2016 \\
107\end{array}$ & $\begin{array}{l}\text { 1. Technological } \\
\text { intervention } \\
\text { 2. Web-based automated } \\
\text { telehealth messaging } \\
\text { programme } \\
\text { 3. Standard care } \\
\text { 4. 90-day follow-up }\end{array}$ & $\begin{array}{l}122 \text { newly } \\
\text { diagnosed OSA } \\
\text { patients } \\
(\mathrm{IG}: n=58 ; \mathrm{CG}: \\
n=64)\end{array}$ & $\begin{array}{l}\text { Patients received CPAP device plus a } \\
\text { pamphlet about U-sleep-a web-based } \\
\text { application which receives CPAP data and } \\
\text { messages patients and providers via text and } \\
\text { email on customizable set rules (i.e. no } \\
\text { CPAP data from patient received for } 2 \\
\text { consecutive days, CPAP usage }<4 \text { h for } 3 \\
\text { consecutive nights, median mask leak }>24 \\
\mathrm{~L} / \text { min for } 2 \text { consecutive days, AHI }>15 / \mathrm{h} \text { for } \\
5 \text { consecutive days, CPAP usage met } \\
\text { Medicare criteria for adherence). When } \\
\text { usage falls, messages are sent to encourage } \\
\text { patients to use CPAP more regularly and } \\
\text { alerts are triggered to providers to further } \\
\text { assist patients in CPAP management. }\end{array}$ & $\begin{array}{l}90 \text { days: No statistically } \\
\text { significant differences found } \\
\text { between IG and CG on average } \\
\text { daily CPAP use }(5.1 \pm 1.9 \text { vs. } \\
4.7 \pm 2.1 \mathrm{~h} / \text { day, respectively, } \\
\mathrm{p}=0.24) \text { or percentage of days } \\
\text { used CPAP } \geq 4 \mathrm{~h}(70.2 \pm 26.7 \mathrm{vs.} \\
63.3 \pm 28.5 \% \text {, respectively, } \\
\mathrm{p}=0.17) .\end{array}$ \\
\hline
\end{tabular}




\begin{tabular}{|c|c|c|c|c|}
\hline $\begin{array}{l}\text { Nilius et } \\
\text { al. } 2019 \\
108\end{array}$ & $\begin{array}{l}\text { 1. Technological } \\
\text { intervention } \\
\text { 2. Telemonitoring plus } \\
\text { support } \\
\text { 3. Standard care } \\
\text { 4. } 6 \text { month follow-up }\end{array}$ & $\begin{array}{l}80 \text { patients with } \\
\text { moderate to severe } \\
\text { OSA and who had } \\
\text { suffered an } \\
\text { ischemic stroke } \\
\text { within the last } 3 \\
\text { months } \\
\text { (IG: } n=40 \text {; CG: } \\
n=40)\end{array}$ & $\begin{array}{l}\text { Patients PAP devices transmitted PAP data } \\
\text { (e.g. adherence, leakage, pressure, AHI) to } \\
\text { an online web portal and was evaluated by } \\
\text { researchers weekly. If mean PAP usage time } \\
\text { had dropped below } 4 \mathrm{~h} / \text { night over a week the } \\
\text { patient was contacted via telephone to } \\
\text { resolve problems and increase motivation } \\
\text { through negatively framed educational } \\
\text { messages and reinforcement of their } \\
\text { knowledge about their OSA treatment by } \\
\text { conducting a standardised semi-structured } \\
\text { clinical interview questionnaire. } \\
\text { Conversations were limited to } 5 \text { minutes and } \\
\text { a personal visit by the service provider was } \\
\text { offered, if problems could not be solved } \\
\text { online or on the telephone. }\end{array}$ & $\begin{array}{l}6 \text { month: Average CPAP daily } \\
\text { usage was significantly better for } \\
\text { the IG compared to CG: }(4.4 \pm 2.5 \\
\text { vs. } 2.1 \pm 2.2 \mathrm{~h} \text {, respectively; } \\
\text { p }=0.000063) \text {. Percentage of days } \\
\text { of CPAP used for } \geq 4 \mathrm{~h} \text { was } \\
\text { significantly better in IG } \\
\text { compared to CG }(57.3 \pm 34.5 \text { vs. } \\
27.5 \pm 32.5 \% \text {, respectively, } \\
p=0.00025) .\end{array}$ \\
\hline $\begin{array}{l}\text { Pengo et } \\
\text { al. } 2018 \\
109\end{array}$ & $\begin{array}{l}\text { 1. Educational } \\
\text { intervention } \\
\text { 2. IG1: received } \\
\text { positively framed } \\
\text { messages about CPAP } \\
\text { IG2: received } \\
\text { negatively framed } \\
\text { messages about CPAP } \\
\text { 3. Standard Care } \\
\text { 4. 6-week follow-up }\end{array}$ & $\begin{array}{l}112 \text { newly } \\
\text { diagnosed OSA } \\
\text { patients } \\
(\mathrm{IG} 1: \mathrm{n}=36 ; \mathrm{IG} 2 \text { : } \\
\mathrm{n}=37 ; \mathrm{CG}: \mathrm{n}=39)\end{array}$ & $\begin{array}{l}\text { Patients were read out either positively (IG1) } \\
\text { or negatively (IG2) framed messages during } \\
\text { their CPAP collection appointment and } \\
\text { during } 6 \text { weekly, 2-3-minute, non-interactive } \\
\text { phone calls by a researcher. During phone } \\
\text { calls patients listened to the researchers' } \\
\text { messages and any questions were directed to } \\
\text { the clinical team. Laminated labels with the } \\
\text { printed framed messages were also attached } \\
\text { to their CPAP machines. }\end{array}$ & $\begin{array}{l}6 \text { week: No significant } \\
\text { differences found between IG1, } \\
\text { IG2 or CG for average daily } \\
\text { CPAP use }(3.5 \pm 2.7 \mathrm{~h} / \text { night vs. } \\
2.6 \pm 2.2 \mathrm{~h} / \text { night vs. } 3.1 \pm 2.7 \\
\text { h/night; respectively } \mathrm{p}=0.679)\end{array}$ \\
\hline
\end{tabular}




\begin{tabular}{|c|c|c|c|c|}
\hline $\begin{array}{l}\text { Pepin et } \\
\text { al. } 2019 \\
116\end{array}$ & $\begin{array}{l}\text { 1. Technological } \\
\text { intervention } \\
\text { 2. Multimodal } \\
\text { telemonitoring web- } \\
\text { based platform } \\
\text { 3. Usual Care } \\
\text { 4. 6-month follow-up }\end{array}$ & $\begin{array}{l}306 \text { patients with } \\
\text { moderate to severe } \\
\text { OSA and at least } \\
\text { one cardiovascular } \\
\text { disease (CVD) or } \\
\text { at elevated risk of } \\
\text { CVD } \\
(\mathrm{IG}: \mathrm{n}=157 \text {; CG: } \\
\mathrm{n}=149)\end{array}$ & $\begin{array}{l}\text { Received remote home telemonitoring } \\
\text { equipment which recorded systolic and } \\
\text { diastolic home self-measured blood pressure, } \\
\text { physical activity as well as CPAP adherence, } \\
\text { leaks, and residual events. The data was } \\
\text { transmitted to medical staff members via } \\
\text { secured websites and provided an integrated } \\
\text { care management system. The system } \\
\text { allocated predefined interventions to home } \\
\text { care providers when for example, side } \\
\text { effects, leaks, residual sleepiness or } \\
\text { persistent residual events were noted by } \\
\text { either the patient via online questionnaires or } \\
\text { the monitoring equipment and action would } \\
\text { be taken to resolve these issues. Physicians } \\
\text { were in charge of the appropriate } \\
\text { management of residual events or CPAP lack } \\
\text { of efficacy. Additional home or sleep clinic } \\
\text { visits were organised when required. }\end{array}$ & $\begin{array}{l}6 \text { month: Average daily CPAP } \\
\text { use was significantly higher in } \\
\text { IG compared to CG }(5.28 \pm 2.23 \\
\text { vs } 4.75 \pm 2.50 \text { h/day, respectively; } \\
\mathrm{p}=0.05) .\end{array}$ \\
\hline
\end{tabular}




\begin{tabular}{|c|c|c|c|c|}
\hline $\begin{array}{l}\text { Sawyer et } \\
\text { al. } 2019 \\
111\end{array}$ & $\begin{array}{l}\text { 1. Pilot Psychosocial } \\
\text { intervention } \\
\text { 2. Tailored intervention } \\
\text { targeting social } \\
\text { cognitive perceptions } \\
\text { of OSA/PAP treatment } \\
\text { 3. Usual care } \\
\text { 4. 1-week \& 1- and 3- } \\
\text { month follow-up }\end{array}$ & $\begin{array}{l}118 \text { newly } \\
\text { diagnosed OSA } \\
\text { adults } \\
\text { (IG: } n=61 ; \text { CG: } \\
n=57)\end{array}$ & $\begin{array}{l}\text { Delivered in } 4 \text { phases: (1) pre-diagnosis, (2) } \\
\text { post-diagnosis using PSG, (3) immediately } \\
\text { post-PAP titration PSG and (4) 1-week post } \\
\text { home PAP use; was 30-60minutes in } \\
\text { duration, was guided by a protocol and } \\
\text { scripted templates and delivered by a trained } \\
\text { registered nurse in either face-to-face } \\
\text { sessions or by telephone. The content } \\
\text { addressed cognitive perceptions of the } \\
\text { diagnosis and treatment, outcome } \\
\text { expectancies with PAP treatment and PAP } \\
\text { treatment self-efficacy, all domains of Social } \\
\text { Cognitive Theory. Participant scores from } \\
\text { the Self-efficacy Measure in Sleep Apnea } \\
\text { (SEMSA), Epworth Sleepiness Scale and } \\
\text { Functional Outcomes of Sleep Questionnaire } \\
\text { were assessed at each of the } 4 \text { phases and } \\
\text { used to tailor the intervention for each } \\
\text { individual. For example, if a participant } \\
\text { scored }>3.0 \text { on a SEMSA subdomain domain } \\
\text { (e.g. risk perception), the intervention } \\
\text { activity addressing that domain was not } \\
\text { addressed in the intervention phase. }\end{array}$ & $\begin{array}{l}\text { No significant differences found } \\
\text { in average PAP use between IG } \\
\text { and CG at } 1 \text {-week }(6.4 \pm 2.01 \\
\text { vs. } 5.8 \pm 1.35 \mathrm{~h} / \text { night, respectively, } \\
\mathrm{p}=0.20), 1 \text {-month }(5.1 \pm 2.05 \mathrm{vs.} \\
5.1 \pm 1.66 \mathrm{~h} / \text { night, respectively, } \\
\mathrm{p}=0.90) \text { and at } 3 \text {-month } \\
(4.8 \pm 2.27 \mathrm{vs.} 4.7 \pm 1.85 \mathrm{~h} / \text { night, } \\
\text { respectively, } \mathrm{p}=0.89) .\end{array}$ \\
\hline $\begin{array}{l}\text { Shapiro } \\
2019^{112}\end{array}$ & $\begin{array}{l}\text { 1. Psychosocial } \\
\text { intervention } \\
\text { 2. CPAP-SAVER based } \\
\text { on Theory of Planned } \\
\text { Behavior plus } \\
\text { Standard Care } \\
\text { 3. Standard Care }\end{array}$ & $\begin{array}{l}66 \text { newly } \\
\text { diagnosed OSA } \\
\text { patients } \\
(\text { IG: } n=33 ; \\
\text { CG:n=33) }\end{array}$ & $\begin{array}{l}\text { All intervention components (unless } \\
\text { specified) were delivered during the first } \\
\text { week of CPAP use and were scripted. It } \\
\text { included: (1) two support phone calls by a } \\
\text { registered nurse during week } 1 \& 2 \text { of CPAP } \\
\text { use focusing on social pressure and building } \\
\text { a subjective norm to adhere to CPAP; (2) a }\end{array}$ & $\begin{array}{l}1 \text { week: No significant } \\
\text { differences found between IG } \\
\text { and CG on weekly average } \\
\text { CPAP use ( } 37.9 \text { vs. } 34.7 \mathrm{~h}, \\
\text { respectively, } \mathrm{t}=-0.834, \mathrm{p}=0.408 \text { ) } \\
\text { and adherence rates }(78.8 \text { vs. } \\
72.7 \% \text {, respectively, }\end{array}$ \\
\hline
\end{tabular}




\begin{tabular}{|c|c|c|c|c|}
\hline & $\begin{array}{l}\text { 4. 1-week \& 1-month } \\
\text { follow-up }\end{array}$ & & $\begin{array}{l}\text { web-based video and educational sheet } \\
\text { delivered and reviewed by a trained research } \\
\text { assistant (RA) with } 21+\text { yrs as a respiratory } \\
\text { therapist. This focused on OSA risks \& } \\
\text { CPAP benefits; and (3) a report card updated } \\
\text { and reviewed with participants by the RA at } \\
\text { week } 1 \& 4 \text { containing personal data on AHI, } \\
\text { CPAP setting use and self CPAP adherence } \\
\text { grades to improve self-efficacy. }\end{array}$ & $\begin{array}{l}\chi 2(1, N=66)=0.083, \mathrm{p}=.774), \\
\text { which adherence was defined as } \\
\geq 4 \mathrm{~h} \text { per night for } 70 \% \text { of the } \\
\text { nights. } \\
1 \mathrm{month} \text { : No significant } \\
\text { differences found between IG } \\
\text { and CG on weekly average } \\
\text { CPAP use }(154.1 \text { vs. } 161.1 \mathrm{~h}, \\
\text { respectively, } \mathrm{t}=0.426, \mathrm{p}=0.672) \\
\text { and adherence rates }(69.7 \mathrm{vs} \text {. } \\
75.8 \% \text {, respectively, } \chi 2(1, N= \\
66)=.08, p=.782) .\end{array}$ \\
\hline $\begin{array}{l}\text { Sweetman } \\
\text { et al. } 2019 \\
113\end{array}$ & $\begin{array}{l}\text { 1. Cognitive behavioural } \\
\text { intervention } \\
\text { 2. Cognitive behavioural } \\
\text { therapy for insomnia } \\
\text { (CBT-I) plus CPAP } \\
\text { usual care } \\
\text { 3. Usual Care } \\
\text { 4. 6-month follow-up }\end{array}$ & $\begin{array}{l}145 \text { participants } \\
\text { with moderate to } \\
\text { severe OSA and } \\
\text { comorbid } \\
\text { insomnia } \\
\text { (IG: } n=72 ; \text { CG: } \\
n=73)\end{array}$ & $\begin{array}{l}4 \text { consecutive weekly } 45 \text {-minute individual } \\
\text { or small-group sessions of CBT-I were } \\
\text { delivered by a psychologist prior to starting } \\
\text { CPAP. CBT-I components included bed } \\
\text { restriction therapy, sleep psychoeducation } \\
\text { and hygiene information, cognitive therapy, } \\
\text { and relapse prevention. Participants were } \\
\text { provided booklets to review concepts of } \\
\text { therapy. Standard CPAP care was delivered } \\
\text { after completion of CBT-I which included a } \\
\text { laboratory CPAP titration appointment with a } \\
\text { sleep technician and CPAP set up } \\
\text { appointments with qualified sleep } \\
\text { nurses/technicians, who reviewed progress at } \\
1 \text { week, } 3 \text { and } 6 \text { months using CPAP data. }\end{array}$ & $\begin{array}{l}6 \text { month: Average nightly CPAP } \\
\text { use was } 60.7 \text { min higher }(\mathrm{CI}=9 \\
\text { to } 113) \text { in } \mathrm{IG}(\mathrm{M}=265.2 \\
\text { min/night, } \mathrm{CI}=226.2 \text { to } 304.2) \\
\text { compared to } \mathrm{CG}(\mathrm{M}= \\
204.5 \mathrm{~min} / \text { night, } \mathrm{CI}=166.3 \text { to } \\
242.7 ; \mathrm{t}(158.36)=2.30, \mathrm{p}= \\
0.023, \mathrm{~d}=0.38) .\end{array}$ \\
\hline $\begin{array}{l}\text { Turino et } \\
\text { al. } 2017\end{array}$ & $\begin{array}{l}\text { 1. Technological } \\
\text { intervention }\end{array}$ & $\begin{array}{l}100 \text { newly } \\
\text { diagnosed OSA }\end{array}$ & $\begin{array}{l}\text { Received a CPAP device equipped with } \\
\text { mobile } 2 \mathrm{G} \text { (GSM/GPRS) technology capable }\end{array}$ & $\begin{array}{l}3 \text { month: No significant } \\
\text { differences between IG and CG }\end{array}$ \\
\hline
\end{tabular}




\begin{tabular}{|c|c|c|c|c|}
\hline 114 & $\begin{array}{l}\text { 1. Telemonitoring based } \\
\text { strategy } \\
\text { 2. Standard Care } \\
\text { 3. 3-month follow-up }\end{array}$ & $\begin{array}{l}\text { patients } \\
\text { (IG: } n=52 ; C G: \\
n=48)\end{array}$ & $\begin{array}{l}\text { of sending information to a web database } \\
\text { relaying daily information on CPAP } \\
\text { adherence, CPAP pressures, mask leak and } \\
\text { residual respiratory events. Automatic alarms } \\
\text { for the provider were generated and then } \\
\text { followed up by the pulmonary specialist } \\
\text { medical officer of the CPAP provider who } \\
\text { contacted the patient and provided individual } \\
\text { problem solving. For example, providing } \\
\text { suggestions on how to minimise unwanted } \\
\text { symptoms such as dry mouth, providing } \\
\text { specific interventions to improve compliance } \\
\text { issues such as mask changing or applying } \\
\text { saline nasal sprays; and providing support } \\
\text { for the patient with CPAP use. }\end{array}$ & $\begin{array}{l}\text { on average nightly CPAP use } \\
(5.1 \pm 2.1 \text { vs. } 4.9 \pm 2.2 \mathrm{~h} / \text { night, } \\
\text { respectively, } p=0.627)\end{array}$ \\
\hline
\end{tabular}

$I G$ intervention group, $C G$ control group, $C P A P$ continuous positive airway pressure, $P A P$ positive airway pressure, $R C T$ randomised control trial, MET motivational enhancement therapy, $O S A$ obstructive sleep apnea, \pm standard deviation, $\mathrm{M}$ mean, CI confidence interval. *This study was an RCT design, but it did not report between-group comparisons in analysis. 